\title{
Interactions in indices of vitamin A, zinc and copper status when these nutrients are fed to rats at adequate and increased levels
}

\author{
BY P. R. SUNDARESAN ${ }^{1}$, SUSAN M. KAUP ${ }^{1}$, PADDY W. WIESENFELD ${ }^{1}$, \\ STUART J. CHIRTEL ${ }^{2}$, SUSAN C. HIGHT ${ }^{3}$ AND JEANNE I. RADER ** \\ ${ }^{1}$ Office of Special Nutritionals, ${ }^{2}$ Office of Scientific Analysis and Support, ${ }^{3}$ Office of Plant and \\ Dairy Foods and Beverages and ${ }^{4}$ Office of Food Labeling, Center for Food Safety and Applied \\ Nutrition, Food and Drug Administration, 200 C Street, SW, Washington, DC 20204, USA
}

(Received 6 December 1994 - Revised 14 August 1995 - Accepted 24 October 1995)

\begin{abstract}
The purpose of the present study was to determine the effects of feeding nutritionally adequate and increased levels of vitamin $A$ (retinyl acetate at 1.4, 34.4, and $206.4 \mathrm{mg} / \mathrm{kg}$ diet) in combination with adequate or increased $\mathrm{Zn}(12$ and $240 \mathrm{mg} / \mathrm{kg}$ ) and $\mathrm{Cu}(5$ and $50 \mathrm{mg} / \mathrm{kg})$ on serum and tissue concentrations of retinol and retinyl palmitate and on indices of $\mathrm{Cu}$ and $\mathrm{Zn}$ status in female Sprague-Dawley rats, and to measure interactive effects of such nutrient imbalances. Rats fed on diets containing 34.4 and $206.4 \mathrm{mg}$ vitamin $\mathrm{A} / \mathrm{kg}$ had higher feed intakes and relative liver weights than those fed on diets containing $1.4 \mathrm{mg}$ vitamin $\mathrm{A} / \mathrm{kg}$. An interaction between dietary $\mathrm{Cu}$ and $\mathrm{Zn}$ and an independent effect of vitamin $A$ affected serum ceruloplasmin oxidase $(E C$ 1.16.3.1) activity. Rats fed on high $\mathrm{Zn}$, adequate-Cu diets ( 240 and $5 \mathrm{mg} \mathrm{Zn}$ and $\mathrm{Cu} / \mathrm{kg}$ respectively) had lower serum ceruloplasmin oxidase levels than rats fed on adequate- $\mathrm{Zn}$, adequate- $\mathrm{Cu}$ diets (12 and $5 \mathrm{mg} \mathrm{Zn}$ and $\mathrm{Cu} / \mathrm{kg}$ respectively). This effect was not observed in rats fed on high-Zn, high-Cu diets (240 and $50 \mathrm{mg} \mathrm{Zn}$ and $\mathrm{Cu} / \mathrm{kg}$ respectively). Alterations in dietary levels of $\mathrm{Cu}$ and vitamin $\mathrm{A}$ independently affected haemoglobin levels. Serum cholesterol concentration was affected by interactions between $\mathrm{Zn}$ and vitamin $\mathrm{A}$ and $\mathrm{Cu}$ and vitamin $A$. Levels of retinol and retinyl palmitate in liver and kidney were significantly higher in rats fed on diets with increased dietary vitamin $A$ than in those fed on diets with adequate vitamin A. Threeway interactions among $\mathrm{Cu}, \mathrm{Zn}$, and vitamin $\mathrm{A}$ affected levels of retinol in serum and liver. Two-way interactions between $\mathrm{Cu}$ and vitamin $\mathrm{A}$ affected liver retinyl palmitate and the sum of liver retinol + retinyl palmitate. An independent effect of dietary $\mathrm{Zn}$ on these variables was also observed. Interactions between $\mathrm{Cu}$ and vitamin $\mathrm{A}$ affected levels of $\mathrm{Cu}$ in liver and kidney, while $\mathrm{Fe}$ and $\mathrm{Zn}$ in kidney were affected by interactions between $\mathrm{Cu}$ and $\mathrm{Zn}$. This study demonstrates that differing interactions among variables of vitamin A metabolism and mineral status occur with higher dietary levels of vitamin $\mathrm{A}, \mathrm{Zn}$ and $\mathrm{Cu}$ in the rat.
\end{abstract}

Vitamin A: Zinc: Copper: Nutrient interactions

Numerous interactions occur among and between nutrients, with mineral-mineral and mineral-vitamin interactions among those most extensively described (Hambridge et al. 1986; Davis \& Mertz, 1987). Many studies have demonstrated the importance of $\mathrm{Zn}$ in the metabolism of vitamin A and its role in the mobilization of vitamin A from liver to the plasma (Brown et al. 1976; Sundaresan et al. 1977; Duncan \& Hurley, 1978; Goodman, 1984; Shankar et al. 1986). Shankar et al. (1986) studied the effects of feeding laboratory chow supplemented with high vitamin A (i.e. 154 times the level recommended by the 
National Research Council (NRC)) in combination with increased Zn (thirty-three times the NRC-recommended level (NRC, 1978)) on total lipids, cholesterol, vitamin A and Zn concentrations in liver and cholesterol in serum in adult female rats. They reported that the concentrations of total liver lipids and liver cholesterol were higher in rats fed on laboratory chow diets with high vitamin $\mathrm{A}$ or a combination of high vitamin $\mathrm{A}$ and high $\mathrm{Zn}$ than in rats fed on a basal diet, suggesting that high vitamin $A$ was affecting these variables regardless of the dietary $\mathrm{Zn}$ level. Furthermore, rats given high dietary $\mathrm{Zn}$ or a combination of high $\mathrm{Zn}$ and high vitamin A had significantly higher serum cholesterol levels, and concentrations of $\mathrm{Zn}$ in the liver were positively correlated with serum cholesterol. Liver and kidney vitamin A levels were significantly lower in rats fed on high-Zn-high-vitamin A diets than in those fed on adequate-Zn-high-vitamin A diets, suggesting altered vitamin A metabolism (e.g. altered absorption, transport, storage or hydrolysis) in the former group. These observations suggested that high $\mathrm{Zn}$ or an altered $\mathrm{Zn}: \mathrm{Cu}$ ratio was influencing these tissue vitamin A levels. In the study of Shankar et al. (1986), the $\mathrm{Zn:Cu}$ ratio in the high-Zn diets was $26: 1$ (w/w) compared with a $\mathrm{Zn}: \mathrm{Cu}$ ratio of $3 \cdot 5: 1(\mathrm{w} / \mathrm{w})$ in the control diet. Shankar et al. (1986) did not specifically examine whether the large decrease in $\mathrm{Cu}$ relative to $\mathrm{Zn}$ in the high- $\mathrm{Zn}$-fed group influenced their results.

The present study was designed to extend the observations of Shankar et al. (1986) by investigating the effects of feeding purified diets containing increased levels of vitamin $A$ in combination with increased $\mathrm{Zn}$, and by determining whether increased dietary $\mathrm{Cu}$, by altering the $\mathrm{Zn}: \mathrm{Cu}$ ratio, affected the responses to increased $\mathrm{Zn}$ and vitamin $\mathrm{A}$. In the present study purified diets were used instead of the chow diets used by Shankar et al. (1986) to allow better control of vitamin A and major and trace mineral composition.

\section{MATERIALS}

Standards

All-trans-retinyl acetate, all-trans-retinol, and all-trans-retinyl palmitate were gifts from Hoffmann-LaRoche (Nutley, NJ, USA). Butylated hydroxytoluene (BHT) was purchased from Sigma Chemical Co. (St Louis, MO, USA). HPLC solvents were obtained from J. T. Baker Chemical Co. (Phillipsburg, NJ, USA).

\section{Diets}

Diet composition was based on that of diet AIN-76A (American Institute of Nutrition, 1977, 1980). Diets, prepared in powdered form, contained $(\mathrm{g} / \mathrm{kg})$ : protein (casein) 200 , choline bitartrate 2, DL-methionine 3, maize starch 150 , maize oil 50, fibre 50, mineral mix 35 , vitamin $\mathrm{mix} 10$, and glucose 500 . Minerals were added to diets to provide calculated concentrations (mg/kg diet): Ca 5100, P 5200, $\mathrm{Na} \mathrm{1090,} \mathrm{K} \mathrm{3600,} \mathrm{Mg} \mathrm{500,} \mathrm{Mn} \mathrm{54,} \mathrm{Fe} \mathrm{50,}$ $\mathrm{Zn} 12$ or $240, \mathrm{Cu} 5$ or $50, \mathrm{I} 0 \cdot 21$, Se $0 \cdot 11$, and $\mathrm{Cr} 2 \cdot 0$. Vitamin A, as retinyl acetate, was added to diets at levels of $1 \cdot 4,34.4$ or $206.4 \mathrm{mg} / \mathrm{kg}$. These levels correspond to 4000,100000 and 600000 IU retinyl acetate respectively. The study had a $2 \times 2 \times 3$ factorial design. Rats ( $n$ 120) were randomly assigned to the twelve experimental diets, ten rats per group.

\section{Experimental animals}

Female Sprague-Dawley rats (22 d old, weighing 46 (SD 5) g) were obtained from Harlan Sprague-Dawley, Indianapolis, IN, USA. Rats were housed singly in suspended stainless steel cages with wire-mesh flooring, fed ad libitum, and weighed three times weekly. Feed consumption was measured weekly. Distilled deionized water was provided ad libitum. Room temperature was maintained at $70-74^{\circ}$. Room lighting provided alternating $12 \mathrm{~h}$ 
periods of light and dark. After 4 weeks, rats were fasted overnight and then killed by $\mathrm{CO}_{2}$ asphyxiation. Blood was collected by cardiac puncture. Serum was prepared and stored at $<-70^{\circ}$ until analysis. Soft tissues were stored at $-17^{\circ}$ until analysis.

The studies reported herein were conducted according to the principles set forth in the Guide for the Care and Use of Laboratory Animals (NRC, 1986).

\section{METHODS}

\section{Analysis of retinol and retinyl palmitate in biological samples}

Serum retinol was extracted by denaturing serum $(1.0 \mathrm{ml}$, rat) with absolute ethanol $(1.0 \mathrm{ml})$ containing the internal standard $(3.46 \mathrm{nmol}$ retinyl acetate) as described by Sundaresan et al. (1994). Liver vitamin A was extracted from samples of approximately $1 \mathrm{~g}$, essentially as described by Sundaresan et al. (1994) except that the tissue homogenate $(10 \mathrm{ml})$ was re-extracted twice with equal volumes $(10 \mathrm{ml})$ of petroleum ether. The combined petroleum ether extracts only (approximately $18 \mathrm{ml}$ ) were evaporated under $\mathrm{N}_{2}$ and dissolved in $1 \mathrm{ml}$ of acetonitrile-butanol $(1: 1 \mathrm{v} / \mathrm{v})$. One whole kidney (approximately $0.8 \mathrm{~g})$ was extracted in the same manner as liver. Portions $(20 \mu \mathrm{l})$ of the final extracts and standards were analysed by reverse-phase HPLC (Beckman model 346 (Beckman Instruments, Inc., Fullerton, CA, USA) equipped with an IBM PS/2 Model 502 data integration system (International Business Machines Corporation, Boca Raton, FL, USA)).

A gradient HPLC analysis was performed using a $5 \mu \mathrm{m}$ Econosphere C18 $4.6 \times 250 \mathrm{~mm}$ column (Alltech Associates, Deerfield, IL, USA) and a $5 \mu \mathrm{m}$ precolumn packed with reverse phase C18 (Separations Group, Hesperia, CA, USA). Retinyl acetate was used as the internal standard. The mobile phase was $100 \%$ methanol (solvent A) and isopropanol-methanol $(50: 50, \mathrm{v} / \mathrm{v}$; solvent B). The gradient procedure at a flow rate of $1.5 \mathrm{ml} / \mathrm{min}$ was as follows: $100 \%$ solvent $A$ was used for $5 \mathrm{~min}$ followed by a 2 min linear gradient to $100 \%$ solvent B, a 9 min hold at $100 \%$ solvent $B$, and then a 2 min gradient back to $100 \%$ solvent $A$. The ultraviolet wavelength detector, set at $325 \mathrm{~nm}$, was used at the maximum sensitivity (0-001 absorbance units, full scale).

Quantitation of retinol and retinyl palmitate in biological samples was achieved from standard curves determined by HPLC of varying concentrations of standards (retinol and retinyl palmitate) and a single concentration of retinyl acetate, and from comparisons of ratios of their respective peak areas to the peak area of the internal standard. Results were corrected for recovery of the internal standard. Concentrations of standards were determined spectrophotometrically.

Linear responses with correlation coefficients of the corresponding regression lines (in parentheses) were observed from 1.36 to $10.91 \mu \mathrm{M}$ for retinol $(r 0.99979, n 12)$ and 1.31 to $10.50 \mu \mathrm{M}$ for retinyl palmitate $(r 0.99959, n 12)$. The mean recovery $(\%)$ of retinyl acetate from three independent experiments was 88 (SD 8.8). The CV for measurement of retinyl acetate, retinol, and retinyl palmitate were 9.9 ( $n$ 28), $4.4(n 16)$ and $6.5 \%$ ( $n$ 13) respectively. The sum of retinol and retinyl palmitate in liver or kidney represents approximately $85-90 \%$ of the total vitamin A content of these tissues. Thus, $10-15 \%$ of total vitamin $\mathrm{A}$ in these tissues is present as esters other than retinyl palmitate. It was not possible to quantitate these retinyl esters due to lack of appropriate standards.

\section{Other analyses}

Haemoglobin was measured with Sigma Diagnostics Kit no. 525. Serum ceruloplasmin (EC 1.16.3.1) was measured by its oxidase activity with $o$-dianisidine dihydrochloride (Schosinsky et al. 1974). Serum cholesterol was measured enzymically using Sigma 
Diagnostics Kit no. 352. Superoxide dismutase activity (Zn-CuSOD, EC 1.15.1.1) in liver homogenates was measured as described by Misra \& Fridovich (1977).

\section{Analysis of minerals in diets and tissues}

Portions of tissues and diets were weighed and wet-digested in mixtures of $\mathrm{HNO}_{3}, \mathrm{HClO}_{4}$ (diets) or $\mathrm{HNO}_{3}, \mathrm{HClO}_{4}$, and $\mathrm{H}_{2} \mathrm{SO}_{4}$ (liver, kidney) (Rader et al. 1986) and analysed by inductively coupled argon plasma-atomic emission spectrometry (ICP-AES) using a sequential Plasma II system (Perkin-Elmer, Norwalk, CT, USA). Analytical wavelengths used for analyses have been reported previously (Rader et al. 1984). Portions of National Institute of Standards and Technology (NIST) Standard Reference Material Bovine Liver 1577 were digested and analysed together with the samples. Values fell within $\pm 5 \%$ of certified values.

\section{Statistical analysis}

Data were subjected to a $2 \times 2 \times 3$-way factorial ANOVA using the SAS general linear models procedure (Statistical Analysis Systems Institute, Cary, NC, USA, version 6.08). All of the hypothesis tests in such a design use a common pooled estimate of the error variance. Thus, it is important that the treatment variances are approximately equal and that there is not a strong association between the variance of the response variable and its mean (Miller, 1986). In the present study the data for vitamin A in liver and kidney showed profound increases in variances with increased dietary vitamin $A$ and with the response means. For example, for the raw data for the variable liver retinol + retinyl palmitate, the ratio of the variance of the $206.4 \mathrm{mg}$ retinyl acetate/ $\mathrm{kg}$ group to that of the $1.4 \mathrm{mg}$ retinyl acetate $/ \mathrm{kg}$ group was almost 15000 . The results of a regression analysis of the relationship between the response mean and the variance suggested that it would be appropriate to analyse the natural logarithms (In) of the liver vitamin A data. The ratio of the variances of the two groups mentioned above was reduced to 1.5 after the $\log$ transformation. The variances of data for liver retinol and retinyl palmitate (see Table 2) were similarly stabilized with the log transformation and the data were then suitable for ANOVA.

The raw data for kidney retinol, retinyl palmitate, and retinol + retinyl palmitate were also not suitable for ANOVA due to the several hundred-fold increase in variance with vitamin A treatment. In contrast to the raw data for vitamin A in liver, however, the natural logarithm was not an appropriate transformation. Consequently, separate two-way ANOVA were performed at each vitamin A treatment level. Comparisons were made between treatment groups only in the absence of any higher level interactions. Hypothesis tests on individual comparisons were performed using the least significant difference $t$ test option in the general linear models procedure. For all tests, $P$ values $<0.05$ were considered to be statistically significant.

\section{RESULTS}

Body-weight gains among diet groups were affected by a two-way interaction between dietary $\mathrm{Zn}$ and vitamin A (Table 1$)$. Weight gain was slightly lower $(6.4 \% ; P=0.0206)$ with $240 \mathrm{mg} \mathrm{Zn} / \mathrm{kg}$ than with $12 \mathrm{mg} \mathrm{Zn} / \mathrm{kg}$. The main effect on feed intake was that of dietary vitamin A: mean intake by rats given $206.4 \mathrm{mg}$ retinyl acetate/ $\mathrm{kg}$ was $5.5 \%$ higher than that of rats given $1.4 \mathrm{mg}$ retinyl acetate $/ \mathrm{kg}(P=0.0014)$. Haemoglobin values in rats given $34.4 \mathrm{mg}$ retinyl acetate $/ \mathrm{kg}$ were about $7 \%$ higher than haemoglobin values in rats given $1.4 \mathrm{mg}$ retinyl acetate $/ \mathrm{kg}(P=0.0113)$. Haemoglobin values were also about $5 \%$ higher in rats given $50 \mathrm{mg} \mathrm{Cu} / \mathrm{kg}$ than in those given $5 \mathrm{mg} \mathrm{Cu} / \mathrm{kg}(P=0.0221)$. Mean 
VITAMIN A, ZINC AND COPPER INTERACTIONS

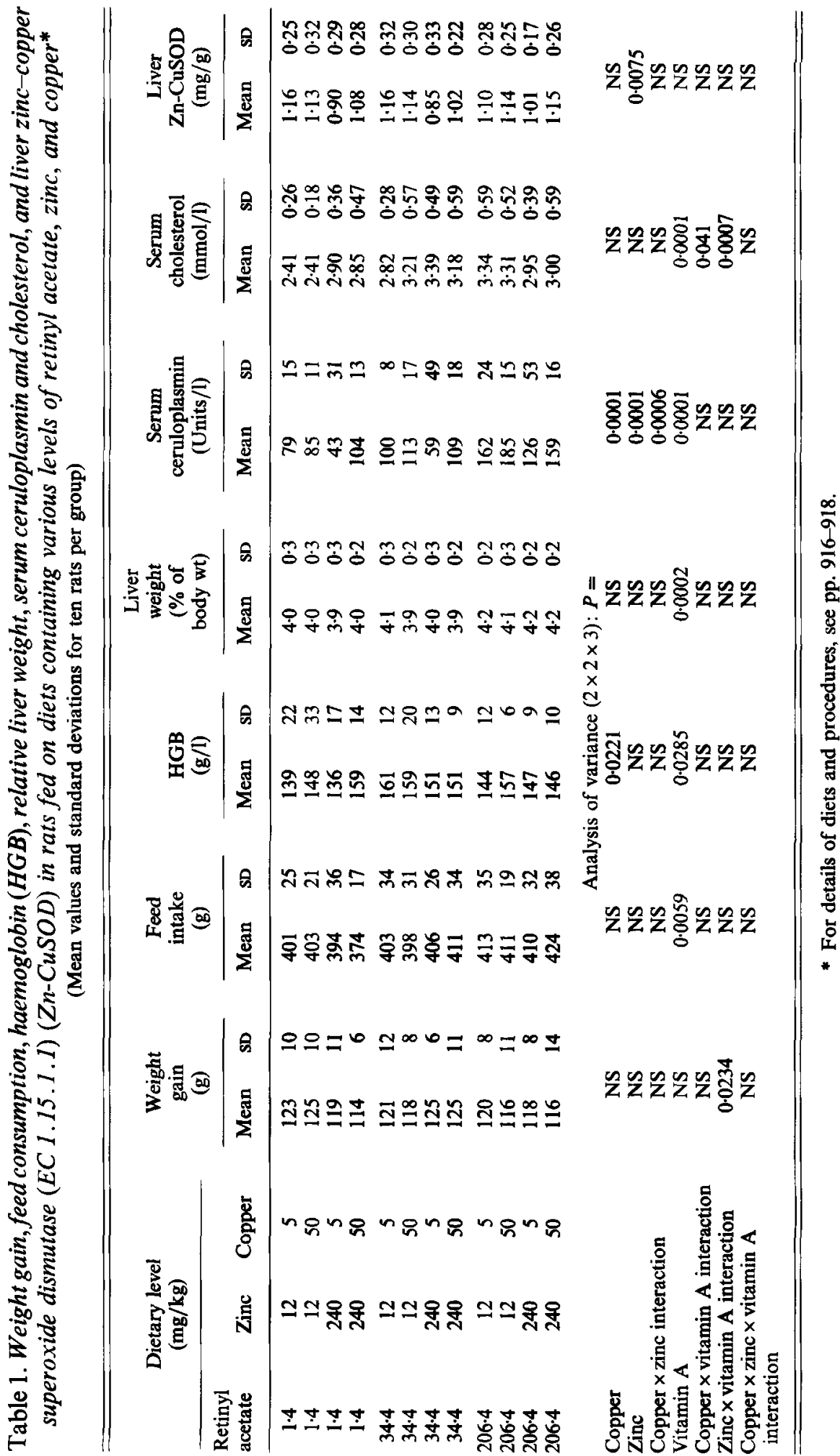




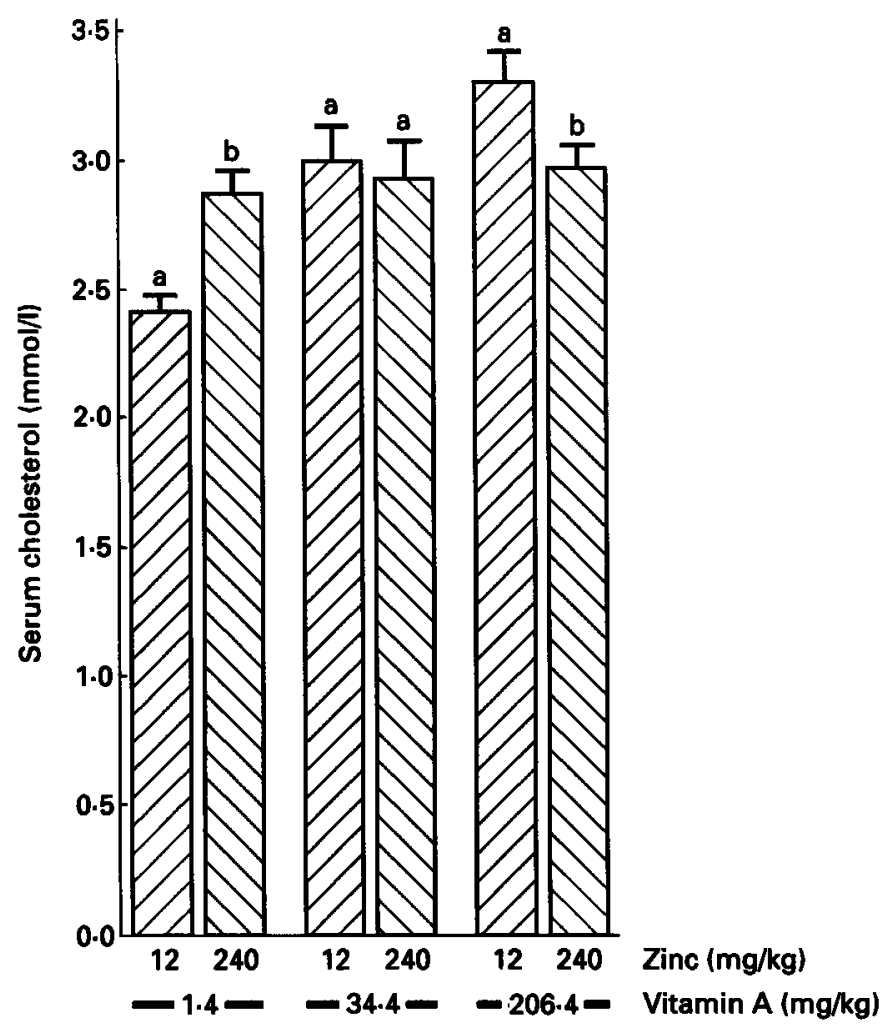

Fig. 1. Graphic representation of the effect of a two-way interaction between zinc and vitamin $\mathbf{A}$ on serum cholesterol concentration in rats. Comparisons between means in the zinc groups were made within each level of dietary vitamin A. The effects of two levels of zinc (12 and $240 \mathrm{mg} / \mathrm{kg}$ ) on serum cholesterol are shown separately for each of the three levels of retinyl acetate tested $(1.4,34.4$ and $206.4 \mathrm{mg} / \mathrm{kg}){ }^{\mathrm{a}, \mathrm{b}}$ Mean values within each dietary vitamin A group not sharing a common letter were significantly different $(P<0.05)$ based on the least significant difference $t$ test using the pooled error variance from the complete model.

relative liver weight was $5 \cdot 3 \%$ higher in rats given $206.4 \mathrm{mg}$ retinyl acetate $/ \mathrm{kg}$ than in those given $1.4 \mathrm{mg}$ retinyl acetate $/ \mathrm{kg}(P=0.002)$. All of these changes are quite modest and may not be biologically significant in this 4-week study.

Serum ceruloplasmin was significantly higher in rats fed on diets with increased dietary vitamin $\mathrm{A}$ (Table 1). A two-way interaction between $\mathrm{Cu}$ and $\mathrm{Zn}$ also affected serum ceruloplasmin activity. Serum ceruloplasmin in rats fed on the $5 \mathrm{mg} \mathrm{Cu} / \mathrm{kg}$ diet was higher with dietary $\mathrm{Zn}$ at $12 \mathrm{mg} / \mathrm{kg}$ than with dietary $\mathrm{Zn}$ at $240 \mathrm{mg} / \mathrm{kg}(P=0.0001)$. There was no significant difference between $\mathrm{Zn}$ treatments when $\mathrm{Cu}$ was given at $50 \mathrm{mg} / \mathrm{kg}$.

Serum cholesterol was affected by interactions between $\mathrm{Cu}$ and vitamin $\mathrm{A}$ and $\mathrm{Zn}$ and vitamin A. When retinyl acetate was given at $34.4 \mathrm{mg} / \mathrm{kg}$, serum cholesterol was about $16 \%$ higher in rats given $50 \mathrm{mg} \mathrm{Cu} / \mathrm{kg}$ than in those given $5 \mathrm{mg} \mathrm{Cu} / \mathrm{kg}(P=0.0026)$. No effects of increased $\mathrm{Cu}$ were observed at dietary levels of retinyl acetate of 1.4 or $206.4 \mathrm{mg} / \mathrm{kg}$. When retinyl acetate was given at $1.4 \mathrm{mg} / \mathrm{kg}$, serum cholesterol was $18.7 \%$ higher in rats given $240 \mathrm{mg} \mathrm{Zn} / \mathrm{kg}$ diet than in those given $12 \mathrm{mg} \mathrm{Zn} / \mathrm{kg} \operatorname{diet}(P=0.0024)$. There was no effect on serum cholesterol of increased dietary $\mathrm{Zn}$ in rats given $34.4 \mathrm{mg}$ retinyl acetate $/ \mathrm{kg}$ diet. At dietary retinyl acetate levels of $206.4 \mathrm{mg} / \mathrm{kg}$, serum cholesterol was about $12 \%$ lower in rats given $240 \mathrm{mg} \mathrm{Zn} / \mathrm{kg}$ than in those given $12 \mathrm{mg} \mathrm{Zn} / \mathrm{kg}$ $(P=0.0203)$. The complexity of this interaction is shown graphically in Fig. 1. 
Table 2. Retinol and retinyl palmitate concentrations in serum and liver of rats fed on diets containing various levels of retinyl acetate, zinc, and copper*

(Mean values and standard deviations for ten rats per group)

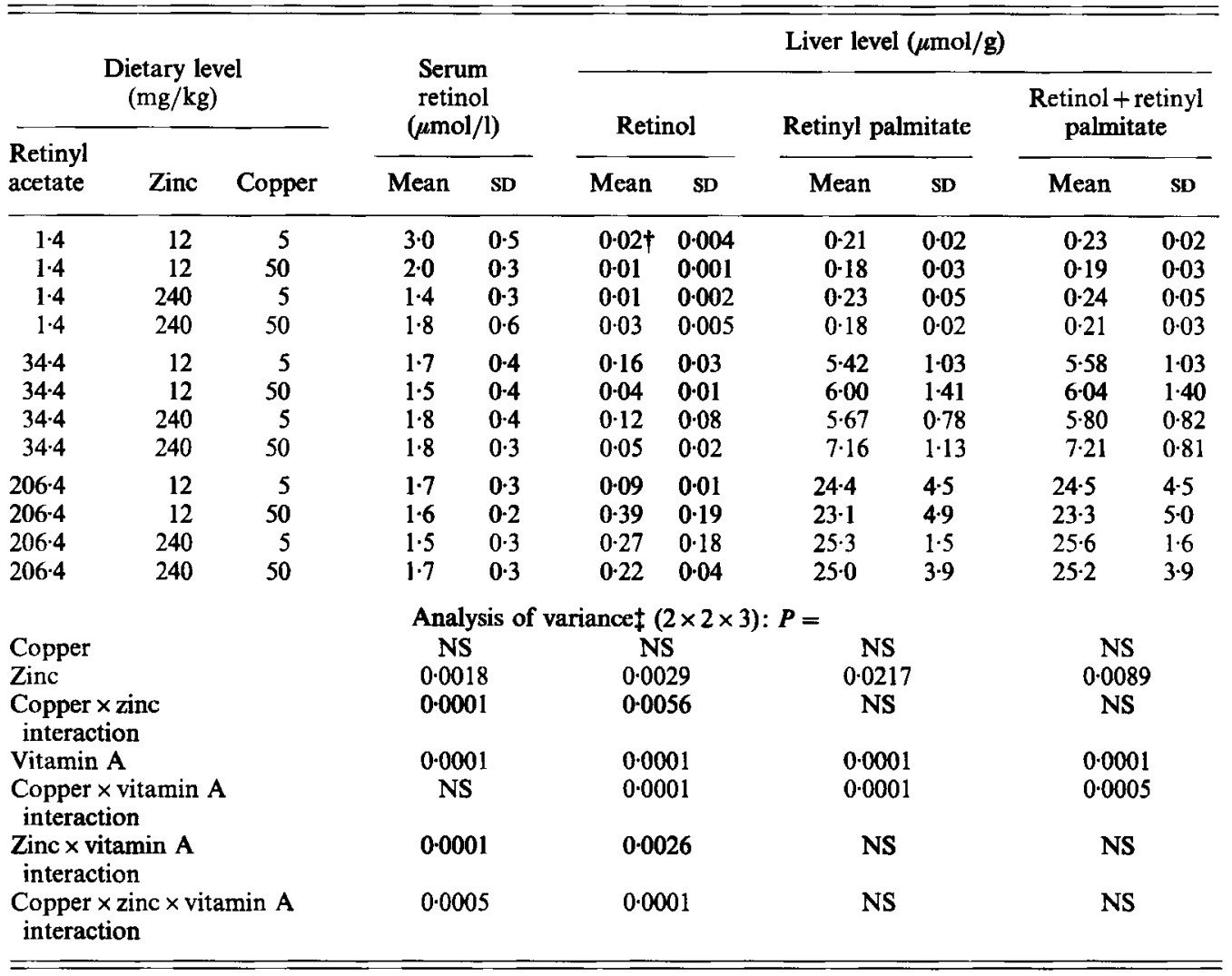

* For details of diets and procedures, see pp. 916-918.

$\dagger n 9$.

\$ The analysis of variance was performed on log-transformed data for all variables above except serum retinol.

The activity of liver $\mathrm{Zn}-\mathrm{CuSOD}$ was affected only by changes in dietary $\mathrm{Zn}$ level, with the enzyme activity lower by about $14 \%$ when $\mathrm{Zn}$ was increased from 12 to $240 \mathrm{mg} / \mathrm{kg}$ diet (Table 1).

Three-way interactions among vitamin $\mathrm{A}, \mathrm{Cu}$, and $\mathrm{Zn}$ affected serum and liver retinol concentrations (Table 2). These interactions are shown graphically in Figs. 2 and 3 respectively. Effects of dietary $\mathrm{Cu}$ and $\mathrm{Zn}$ on serum retinol were much more pronounced in rats given $1.4 \mathrm{mg}$ retinyl acetate $/ \mathrm{kg}$ diet than in those given the higher levels of vitamin $\mathrm{A}$ (Fig. 2). In the case of liver retinol, effects of dietary $\mathrm{Cu}$ and $\mathrm{Zn}$ were more pronounced in rats fed on the two lower levels of vitamin $\mathrm{A}$. Two-way interactions between $\mathrm{Cu}$ and vitamin $\mathrm{A}$ and a main effect of $\mathrm{Zn}$ were responsible for changes in liver retinyl palmitate and the sum of liver retinol + retinyl palmitate (Table 2).

Separate two-way ANOVA were performed for vitamin A variables in kidney at the three levels of dietary vitamin A tested (Table 3). When rats were fed on the $1.4 \mathrm{mg}$ retinyl acetate $/ \mathrm{kg}$ diet, kidney retinol, retinyl palmitate, and the sum of retinol + retinyl palmitate 


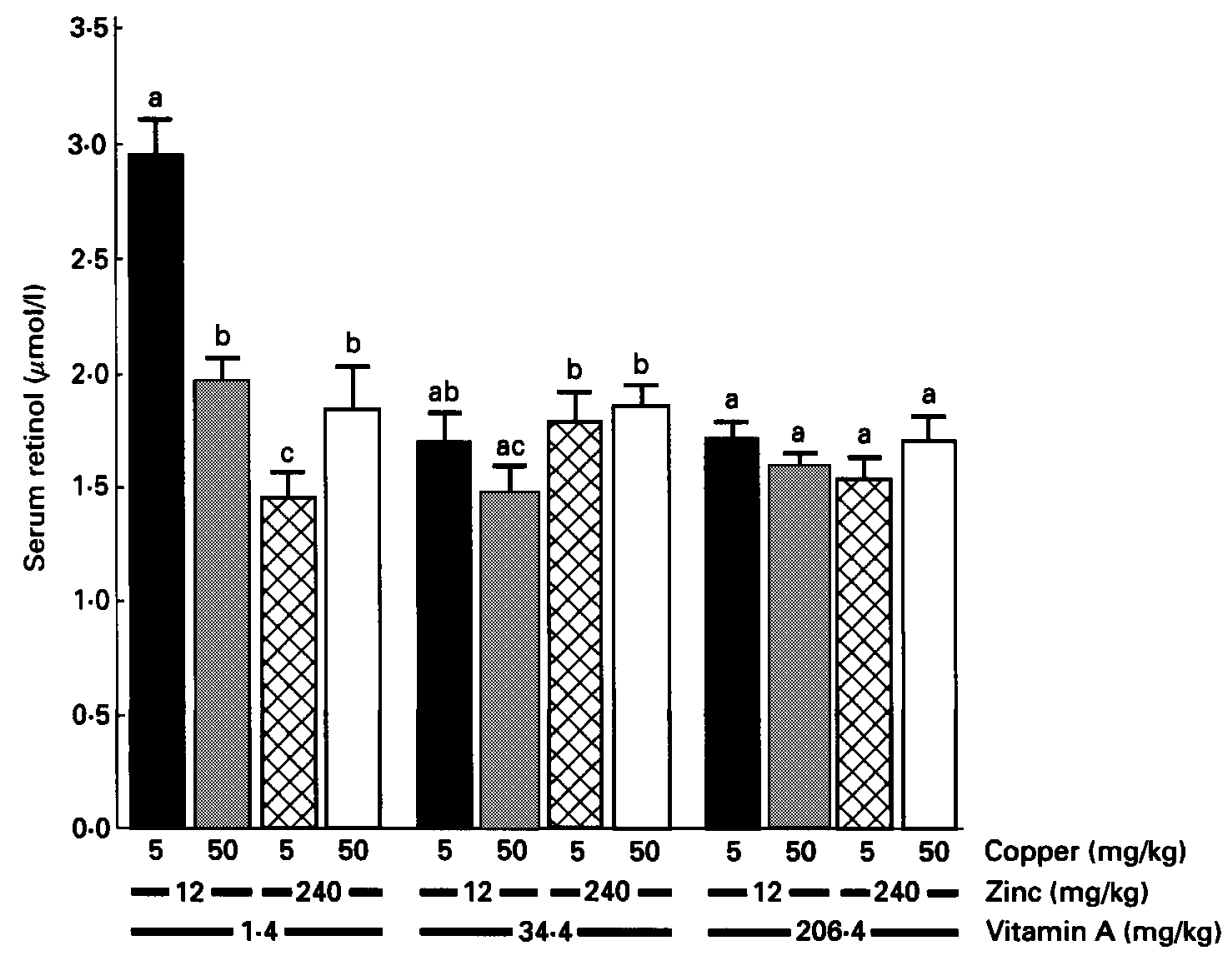

Fig. 2. Graphic representation of the effect of a three-way interaction among copper, zinc and vitamin $A$ on serum retinol concentration in rats. Comparisons between means in the copper and zinc groups were made within each level of dietary vitamin A. The effects of two levels of copper $(5$ and $50 \mathrm{mg} / \mathrm{kg})$ and two levels of zinc (12 and $240 \mathrm{mg} / \mathrm{kg}$ ) on serum retinol are shown in separate panels for each of the three levels of retinyl acetate tested (1.4, 34.4 and $206.4 \mathrm{mg} / \mathrm{kg}$ ). ${ }^{\mathrm{a}, \mathrm{b}, \mathrm{c}}$ Mean values within each dietary vitamin A group not sharing a common letter were significantly different $(P<0.05)$ based on the least significant difference $t$ test using the pooled error variance from the complete model.

were significantly lower with $240 \mathrm{mg} \mathrm{Zn} / \mathrm{kg}$ diet than with $12 \mathrm{mg} \mathrm{Zn} / \mathrm{kg}$ diet. This effect of increased dietary $\mathrm{Zn}$ was not observed at the higher levels of vitamin $\mathrm{A}$ tested.

Concentrations of $\mathrm{Fe}$ in liver were affected by levels of dietary vitamin $\mathrm{A}, \mathrm{Cu}$, and $\mathrm{Zn}$. An interaction between $\mathrm{Cu}$ and $\mathrm{Zn}$ affected $\mathrm{Fe}$ levels in kidney (Table 4). In rats given $5 \mathrm{mg}$ $\mathrm{Cu} / \mathrm{kg}$ diet, kidney $\mathrm{Fe}$ was lower by about $9 \%$ when dietary $\mathrm{Zn}$ was increased from 12 to $240 \mathrm{mg} / \mathrm{kg}(P=0.0005)$. This effect of $\mathrm{Zn}$ was not observed in rats given $50 \mathrm{mg} \mathrm{Cu} / \mathrm{kg}$ diet.

$\mathrm{Cu}$ levels in liver were significantly affected by two-way interactions between $\mathrm{Cu}$ and vitamin $\mathrm{A}$ and $\mathrm{Zn}$ and vitamin $\mathrm{A}$. When diets contained 1.4 or $34.4 \mathrm{mg}$ retinyl acetate $/ \mathrm{kg}$, liver $\mathrm{Cu}$ levels were about 31 and $29 \%$ higher respectively in rats given $50 \mathrm{mg} \mathrm{Cu} / \mathrm{kg}$ than in those given $5 \mathrm{mg} \mathrm{Cu} / \mathrm{kg}$ ( $P=0.0001$ for both comparisons). At the highest level of vitamin A tested, however, the difference between liver $\mathrm{Cu}$ values in rats given $50 \mathrm{v.} 5 \mathrm{mg}$ $\mathrm{Cu} / \mathrm{kg}$ was considerably smaller $(13 \%, P=0.0039)$.

Kidney $\mathrm{Cu}$ was affected by a $\mathrm{Cu} \times$ vitamin $\mathrm{A}$ interaction similar to that observed for liver $\mathrm{Cu}$. When diets contained 1.4 or $34.4 \mathrm{mg}$ retinyl acetate $/ \mathrm{kg}$, kidney $\mathrm{Cu}$ levels were about 32 and $27 \%$ higher respectively in rats given $50 \mathrm{mg} \mathrm{Cu} / \mathrm{kg}$ than in those given $5 \mathrm{mg} \mathrm{Cu} / \mathrm{kg}$ $(P=0.0001$ for both comparisons). At the highest level of vitamin A tested, however, the difference between kidney $\mathrm{Cu}$ values in rats given 50 v. $5 \mathrm{mg} \mathrm{Cu} / \mathrm{kg}$ was smaller $(12 \%$, 


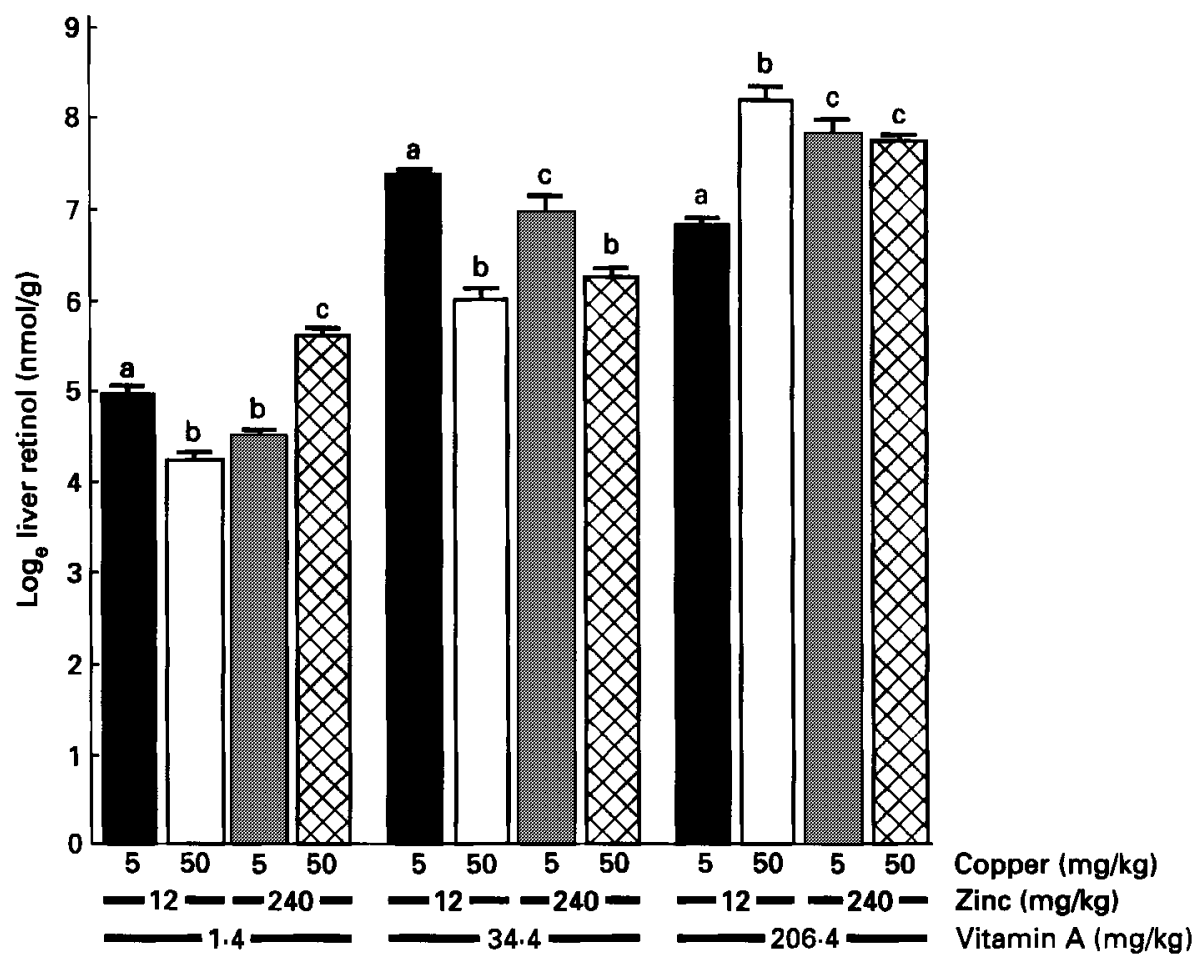

Fig. 3. Graphic representation of the effect of a three-way interaction among copper, zinc, and vitamin $A$ on liver retinol concentration in rats. Comparisons between means in the copper and zinc groups were made within each level of dietary vitamin A. The effects of two levels of copper $(5$ and $50 \mathrm{mg} / \mathrm{kg})$ and two levels of zinc (12 and $240 \mathrm{mg} / \mathrm{kg}$ ) on liver retinol (log scale) are shown in separate panels for each of the three levels of retinyl acetate tested $(1 \cdot 4,34.4$ and $206.4 \mathrm{mg} / \mathrm{kg}){ }^{\mathrm{a}, \mathrm{b}, \mathrm{c}}$ Mean values within each dietary vitamin $\mathrm{A}$ group not sharing a common letter were significantly different $(P<0.05)$ based on the least significant difference $t$ test using the pooled error variance from the complete model.

$P=0.021)$. A main effect of dietary $\mathrm{Zn}$ on kidney $\mathrm{Cu}(P=0.0012)$ was observed (Table 4).

$\mathrm{Zn}$ in liver was sensitive to a main effect of dietary $\mathrm{Cu}$ as well as to a $\mathrm{Zn} \times$ vitamin $\mathrm{A}$ interaction (Table 4). In contrast, $\mathrm{Zn}$ in kidney was not affected by dietary vitamin A but was affected by an interaction between $\mathrm{Zn}$ and $\mathrm{Cu}$. Kidney $\mathrm{Ca}$ was about $30 \%$ lower in rats given $240 \mathrm{mg} \mathrm{Zn} / \mathrm{kg}$ diet than in those given $12 \mathrm{mg} \mathrm{Zn} / \mathrm{kg}$ diet $(P=0.006)$ (Table 4).

\section{DISCUSSION}

There is increasing evidence that significant interactions occur between and among essential nutrients at levels that are not considered to be toxic. The NRC-recommended dietary levels of vitamin $\mathrm{A}$ (as retinyl acetate), $\mathrm{Zn}$, and $\mathrm{Cu}$ for rats are $1.38,12$ and $5 \mathrm{mg} / \mathrm{kg}$ respectively (NRC, 1978). Levels of retinyl acetate (34.4 and $206.4 \mathrm{mg} / \mathrm{kg}), \mathrm{Zn}(240 \mathrm{mg} / \mathrm{kg})$ and $\mathrm{Cu}(50 \mathrm{mg} / \mathrm{kg})$ in the present study were chosen to provide significantly increased but not toxic intakes. Dietary levels were 25- and 150- (retinyl acetate), 20- ( $\mathrm{Zn})$, and 10- (Cu) fold higher than NRC recommendations. No signs of hypervitaminosis A were observed in our study at the levels of vitamin A fed.

Pronounced $\mathrm{Cu}$ depletion has been reported in weanling rats fed on diets containing very low levels of dietary $\mathrm{Cu}(<0.5 \mathrm{mg} \mathrm{Cu} / \mathrm{kg} \mathrm{diet})$ for about 4 weeks (Rader et al. 1991). In 
Table 3. Retinol and retinyl palmitate concentrations in kidney of rats fed on diets containing various levels of retinyl acetate, zinc, and copper*

(Mean values and standard deviations for ten rats per group)

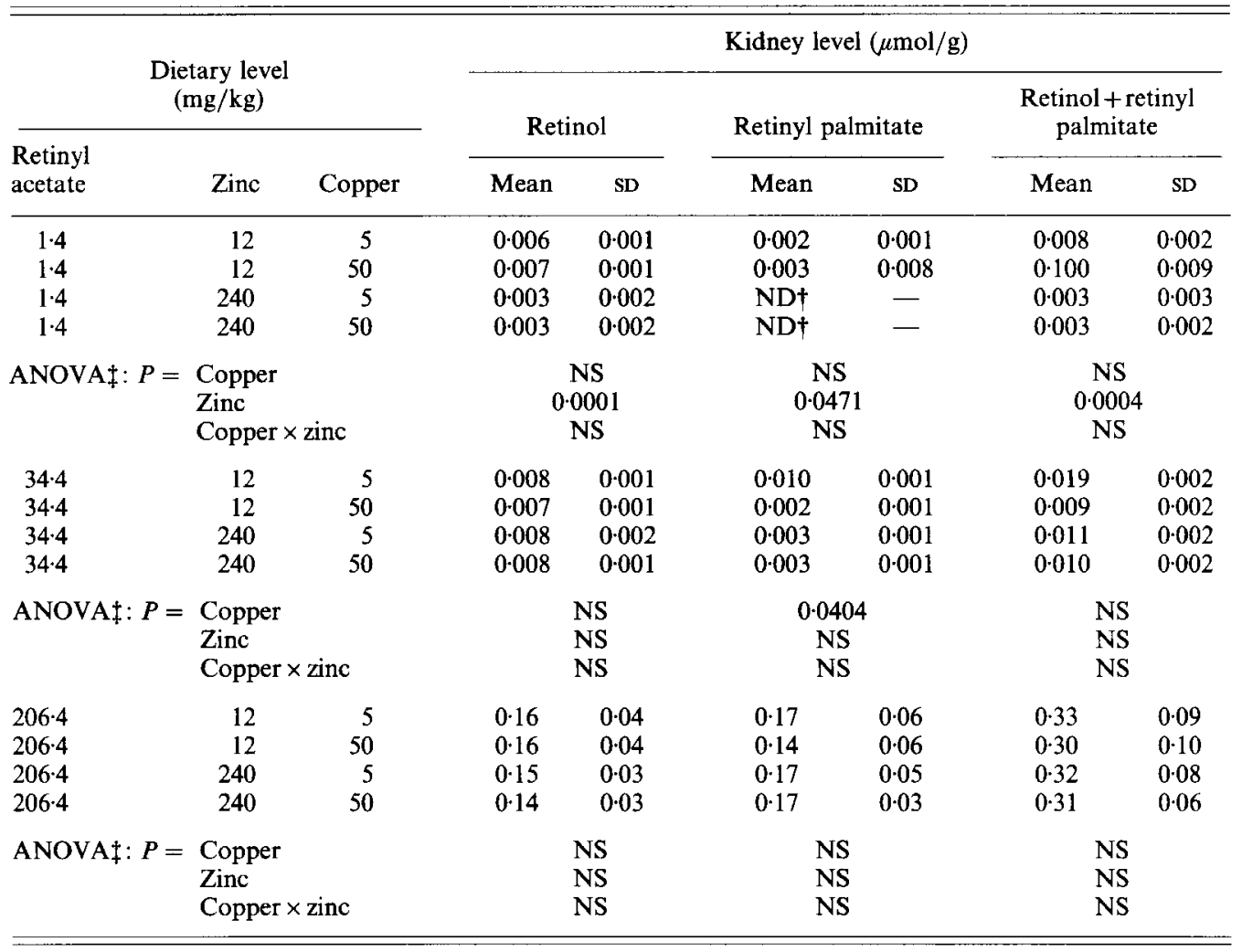

ND, not detected.

* For details of diets and procedures, see pp. 916-918.

$\dagger$ The limit of detection for the analysis of retinyl palmitate is $0.44 \mu \mathrm{M}$.

$\ddagger$ The analysis of variance was performed on raw data.

the present study we observed changes consistent with $\mathrm{Cu}$ depletion (e.g. lower levels of serum ceruloplasmin, kidney $\mathrm{Cu}$, and of liver $\mathrm{Zn}-\mathrm{CuSOD}$ ) in rats given $240 \mathrm{mg} \mathrm{Zn} / \mathrm{kg}$ diet even when adequate $\mathrm{Cu}(5 \mathrm{mg} / \mathrm{kg})$ was included in the diets. Serum ceruloplasmin oxidase activity was clearly influenced by a $\mathrm{Cu} \times \mathrm{Zn}$ interaction. Serum ceruloplasmin oxidase levels were significantly higher in rats fed on diets containing $240 \mathrm{mg} \mathrm{Zn}$ and $50 \mathrm{mg} \mathrm{Cu} / \mathrm{kg}$ than in those fed on diets with $240 \mathrm{mg} \mathrm{Zn}$ and $5 \mathrm{mg} \mathrm{Cu} / \mathrm{kg}$.

Several studies have examined the effects of changes in dietary $\mathrm{Zn}$ alone or in combination with changes in other nutrients on plasma cholesterol levels. Klevay (1973) reported an increase in plasma cholesterol concentration in rats provided with drinking water in which the $\mathrm{Zn}: \mathrm{Cu}$ ratio was 40:1 (w/w) for 45-151 d, and Koo \& Williams (1981) reported that acute dietary $\mathrm{Zn}$ depletion (dietary $\mathrm{Zn}<0.4 \mathrm{mg} / \mathrm{kg}$ ) caused a reduction in total serum cholesterol concentration in rats. We observed interactions between $\mathrm{Cu}$ and vitamin $A$ and between $\mathrm{Zn}$ and vitamin $\mathrm{A}$ in their effect on serum cholesterol levels under the conditions of the present study, but we did not observe an interaction between $\mathrm{Zn}$ and $\mathrm{Cu}$. The interactive effect of $\mathrm{Zn}$ and vitamin $\mathrm{A}$ was the predominant influence on serum 
VITAMIN A, ZINC AND COPPER INTERACTIONS

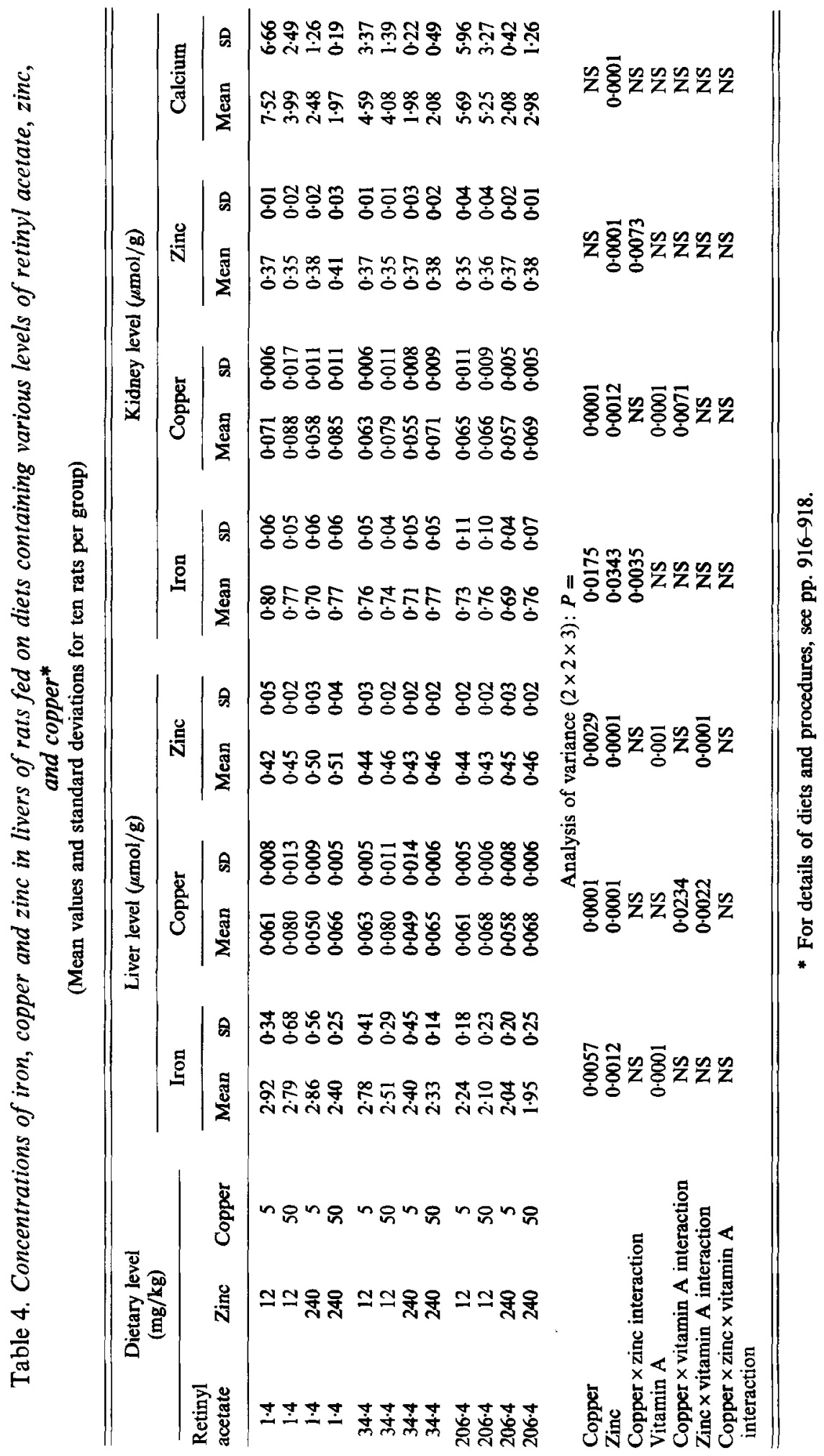


cholesterol (Table 1). At the highest level of vitamin A tested, serum cholesterol concentration was significantly higher in rats given $240 \mathrm{mg} \mathrm{Zn} / \mathrm{kg}$ diet than in those given $12 \mathrm{mg} \mathrm{Zn} / \mathrm{kg}$ diet. This finding confirms the observations of Shankar et al. (1986) on the effects of high dietary $\mathrm{Zn}$ on serum cholesterol levels. It is clear from the graphical presentation in Fig. 1 that effects that occur at lower levels of nutrient intake are not necessarily the same as those that occur with increased intakes of the same nutrients.

We measured liver superoxide dismutase activity because of its sensitivity to changes in Cu status (Fields et al. 1984a, $b$; Reicks \& Rader, 1990). Like serum ceruloplasmin oxidase activity, liver superoxide dismutase activity was significantly lower in rats given $240 \mathrm{mg}$ $\mathrm{Zn} / \mathrm{kg}$ diet than in those given $12 \mathrm{mg} \mathrm{Zn} / \mathrm{kg}$ diet. We observed no other main effects or interactive effects on the activity of this enzyme.

Although interactions between $\mathrm{Zn}$ and $\mathrm{Cu}$ and between $\mathrm{Zn}$ and vitamin $\mathrm{A}$ have been well described, less is known about interactions between $\mathrm{Cu}$ and vitamin $\mathrm{A}$. Retinol and $\mathrm{Cu}$ are stored preferentially in liver and carried in blood plasma bound to retinol binding protein and ceruloplasmin respectively (Goodman, 1984; Cousins, 1985). Complex interactions between retinol and $\mathrm{Cu}$ have been reported in chronic $\mathrm{Cu}$ poisoning in sheep (Moore et al. 1972), but little is known about interactions between $\mathrm{Cu}$ and vitamin $\mathrm{A}$ under more usual circumstances.

The effect of a three-way interaction among $\mathrm{Cu}, \mathrm{Zn}$, and vitamin $\mathrm{A}$ on serum retinol level is presented graphically in Fig. 2. The three panels depict the relationship between $\mathrm{Cu}$ and $\mathrm{Zn}$ separately for each dietary level of vitamin $\mathrm{A}$. The strong interaction is reflected by marked differences in effects of these minerals at different dietary levels of vitamin $\mathbf{A}$. In general, effects of both minerals on serum retinol are more pronounced in rats fed on the lowest level of vitamin A tested. A similar three-way interaction among $\mathrm{Cu}, \mathrm{Zn}$, and vitamin A on liver retinol is shown in Fig. 3. Profound effects of changes in levels of dietary $\mathrm{Zn}$ and $\mathrm{Cu}$ occurred in rats fed on the two lower doses of vitamin $\mathrm{A}$ tested.

We observed higher serum ceruloplasmin oxidase activity with higher vitamin A contents in the diets. These findings are in agreement with results reported by Barber \& Cousins (1987), who described the induction of serum ceruloplasmin oxidase activity by single high doses of 13-cis-retinoic acid $(150 \mathrm{mg} / \mathrm{kg})$ in vitamin A-repleted rats. The same authors also demonstrated the induction of ceruloplasmin oxidase activity in vitamin A-deficient rats repleted with $100 \mu \mathrm{g}$ 13-cis-retinoic acid given orally every day for up to $5 \mathrm{~d}$ or $100 \mu \mathrm{g}$ retinyl acetate given orally every day for $5 \mathrm{~d}$.

About $90 \%$ of plasma $\mathrm{Cu}$ is found in ceruloplasmin in normal mammals and highly significant correlations have been demonstrated between ceruloplasmin levels and plasma, serum, and whole-blood Cu levels (Davis \& Mertz, 1987). Our finding that a 10-fold increase in dietary $\mathrm{Cu}$ had no significant effect on serum ceruloplasmin oxidase activity is consistent with observations that moderate additions of $\mathrm{Cu}$ to normal diets have little effect on blood $\mathrm{Cu}$ concentration. For example, Milne \& Weswig (1968) found no significant differences in ceruloplasmin activity in rats receiving diets containing 10, 50, 100 or $200 \mathrm{mg}$ $\mathrm{Cu} / \mathrm{kg}$, and reported no increase in plasma $\mathrm{Cu}$ level in rats when the $\mathrm{Cu}$ content of the diet was increased from 10 to $50 \mathrm{mg} / \mathrm{kg}$. Plasma $\mathrm{Cu}$, however, doubled from $1 \cdot 16$ to $2.34 \mu \mathrm{g} / \mathrm{ml}$ when dietary $\mathrm{Cu}$ was increased from 50 to $100 \mathrm{mg} / \mathrm{kg}$.

In the present study, serum ceruloplasmin oxidase activity was strongly influenced by an interaction between $\mathrm{Zn}$ and $\mathrm{Cu}$. Serum ceruloplasmin oxidase activity was almost $50 \%$ higher in rats given adequate- $\mathrm{Cu}$, adequate- $\mathrm{Zn}$ diets ( 5 and $12 \mathrm{mg} \mathrm{Cu}$ and $\mathrm{Zn}$ respectively) than in those fed on diets with adequate $\mathrm{Cu}$ and high $\mathrm{Zn}(5$ and $240 \mathrm{mg} \mathrm{Cu}$ and $\mathrm{Zn}$ respectively). However, when $\mathrm{Cu}$ was included at $50 \mathrm{mg} / \mathrm{kg}$ the effect of high dietary $\mathrm{Zn}$ on serum ceruloplasmin oxidase activity was not observed. Elements such as $\mathrm{Zn}$ or $\mathrm{Cd}$ can depress $\mathrm{Cu}$ absorption and can reduce plasma $\mathrm{Cu}$ concentrations when ingested at high 
dietary levels. Campbell \& Mills (1974) reported that weanling rats given supplemental $\mathrm{Zn}$ at levels as low as $300 \mathrm{mg} / \mathrm{kg}$ in diets marginally adequate in $\mathrm{Cu}($ e.g. $2.6 \mathrm{mg} \mathrm{Cu} / \mathrm{kg}$ ) had levels of plasma ceruloplasmin oxidase activity that were $63 \%$ of those of rats fed on the control diet (e.g. without supplemental $\mathrm{Zn}$ ). Rats given supplemental $\mathrm{Zn}$ at levels of $1000 \mathrm{mg} / \mathrm{kg}$ diet had plasma ceruloplasmin levels that were $22 \%$ of those of rats fed on the control diet. Diets containing $1000 \mathrm{mg} \mathrm{Zn} / \mathrm{kg}$ also reduced growth and reduced plasma $\mathrm{Cu}$ concentrations by $89 \%$ and liver $\mathrm{Cu}$ by $47 \%$. Thus, levels of dietary $\mathrm{Zn}$ at which toxic effects are evident depend on the dietary $\mathrm{Zn}: \mathrm{Cu}$ ratio.

In the present study, effects of $\mathrm{Zn}$, as evidenced by lower levels of $\mathrm{Cu}$ in liver and kidney, were observed at a $\mathrm{Zn}$ level of $240 \mathrm{mg} / \mathrm{kg}$ when dietary $\mathrm{Cu}$ level was $5 \mathrm{mg} / \mathrm{kg}$. In addition, at the highest level of retinyl acetate tested $(206.4 \mathrm{mg} / \mathrm{kg})$ the effect of increased dietary $\mathrm{Zn}$ on $\mathrm{Cu}$ levels was less pronounced both in liver and in kidney.

Concentrations of $\mathrm{Fe}$ in liver were sensitive to changes in dietary vitamin $\mathrm{A}$ levels and were significantly lower in rats receiving high dietary vitamin $\mathbf{A}$ than in those given adequate dietary vitamin A (Table 4). Similar results were reported by Staab et al. (1984), who demonstrated that a high vitamin A intake $(21.9 \mathrm{mg}$ retinyl palmitate $/ \mathrm{kg}$; $40000 \mathrm{IU} / \mathrm{kg}$ ) was associated with significantly lower liver Fe levels in weanling rats. The authors proposed that vitamin A was involved in the regulation of Fe release from liver.

Liver Fe was also lower when dietary $\mathrm{Cu}$ was $50 \mathrm{mg} / \mathrm{kg}$ than when it was $5 \mathrm{mg} / \mathrm{kg}$ and when dietary $\mathrm{Zn}$ was $240 \mathrm{mg} / \mathrm{kg}$ than when it was $12 \mathrm{mg} / \mathrm{kg}$ regardless of the level of dietary vitamin $\mathrm{A}$. The effects of vitamin $\mathrm{A}, \mathrm{Zn}$, and $\mathrm{Cu}$ on liver $\mathrm{Fe}$ appeared to represent independent actions of these nutrients. These results appear to be tissue-specific as well, since a $\mathrm{Cu}-\mathrm{Zn}$ interaction was observed with kidney $\mathrm{Fe}$ but not with liver $\mathrm{Fe}$. Kidney $\mathrm{Ca}$ was significantly lower in rats fed on diets with $240 \mathrm{mg} \mathrm{Zn} / \mathrm{kg}$ than in those fed on diets with $12 \mathrm{mg} \mathrm{Zn} / \mathrm{kg}$ at all levels of vitamin A tested.

\section{Conclusions}

This study has demonstrated that, in the rat, when several components of the diet are increased simultaneously, interactions occur that affect a wide range of variables related to status for specific nutrients. In addition, different effects on status indicators occur as dietary levels of the nutrients are increased, making it difficult to predict the effects of changes in concentrations of nutrients.

The authors gratefully acknowledge the excellent technical assistance of Mrs Edythe Smith, Ms Clarisse Jones, and Ms Sun-Mi Ahn.

\section{REFERENCES}

American Institute of Nutrition (1977). Report of the American Institute of Nutrition ad hoc committee on standards for nutritional studies. Journal of Nutrition 107, 1340-1348.

American Institute of Nutrition (1980). Second report of the ad hoc committee on standards for nutritional studies. Journal of Nutrition 110, 1726.

Barber, E. F. \& Cousins, R. J. (1987). Induction of ceruloplasmin synthesis by retinoic acid in rats: influence of dietary copper and vitamin A status. Journal of Nutrition 117, 1615-1622.

Brown, E. D., Chan, W. \& Smith, J. C. Jr (1976). Alterations in vitamin A metabolism during zinc deficiency and food and growth restriction. Journal of Nutrition 106, 563-568.

Campbell, J. K. \& Mills, C. F. (1974). Effects of dietary cadmium and zinc on rats maintained on diets low in copper. Proceedings of the Nutrition Society 35, 15A.

Cousins, R. J. (1985). Absorption, transport and hepatic metabolism of copper and zinc: special reference to metallothionein and ceruloplasmin. Physiological Review 65, 238-309.

Davis, G. K. \& Mertz, W. (1987). Copper. In Trace Elements in Human and Animal Nutrition, pp. 301-364 [W. Mertz, editor]. New York: Academic Press.

Duncan, J. R. \& Hurley, L. S. (1978). An interaction between zinc and vitamin A in pregnant and fetal rats. Journal of Nutrition 108, 1431-1438. 
Fields, M., Ferretti, R. J., Smith, J. C. \& Reiser, S. (1984a). The interaction of dietary carbohydrates with copper deficiency. American Journal of Clinical Nutrition 39, 289-295.

Fields, M., Ferretti, R. J., Smith, J. C. \& Reiser, S. (1984b). Interaction between dietary carbohydrate and copper nutriture on lipid peroxidation in rat tissues. Biological Trace Element Research 6, 379-391.

Goodman, D. S. (1984). Plasma retinol-binding protein. In The Retinoids, vol. 2, pp. 55-62 [M. B. Sporn, A. B. Roberts and D. S. Goodman, editors]. New York: Academic Press.

Hambridge, K. M., Casey, C. E. \& Krebs, N. F. (1986). Zinc. In Trace Elements in Human and Animal Nutrition, pp. 1-137 [W. Mertz, editor]. New York: Academic Press.

Klevay, L. M. (1973). Hypercholesterolemia in rats produced by an increase in the ratio of zinc to copper ingested. American Journal of Clinical Nutrition 26, 1060-1068.

Koo, S. I. \& Williams, D. A. (1981). Relationship between the nutritional status of zinc and cholesterol concentration of serum lipoproteins in adult male rats. American Journal of Clinical Nutrition 34, 2376-2381.

Miller, R. G. Jr (1986). Beyond Anova, Basics of Applied Statistics, pp. 117-163. New York: John Wiley and Sons.

Milne, D. B. \& Weswig, P. H. (1968). Effect of supplementary copper on blood and liver copper-containing fractions in rats. Journal of Nutrition 95, 429-433.

Misra, H. P. \& Fridovich, I. (1977). Superoxide dismutase: a photochemical augmentation assay. Archives of Biochemistry and Biophysics 131, 308-312.

Moore, T., Sharman, I. M., Todd, J. R. \& Thompson, R. H. (1972). Copper and vitamin A concentrations in the blood of normal and Cu-poisoned sheep. British Journal of Nutrition 28, 23-30.

National Research Council (1978). Nutrient requirements of the laboratory rat. In Nutrient Requirements of Laboratory Animals, 3rd revised ed., pp. 7-37. Washington, DC: National Academy of Sciences.

National Research Council (1986). Guide for the Care and Use of Laboratory Animals. National Institutes of Health Publication no. 86-23. Bethesda: NIH.

Rader, J. I., Hight, S. C., Whittaker, P. \& Capar, S. G. (1991). Interactions among dietary tin, copper, and carbohydrate in Long-Evans rats. Journal of Trace Elements in Experimental Medicine 4, 135-147.

Rader, J. I., Wolnik, K. A., Gaston, C. M., Celesk, E. M., Peeler, J. T., Fox, M. R. S. \& Fricke, F. L. (1984). Trace element studies in weanling rats: maternal diets and baseline tissue mineral values. Journal of Nutrition 114, 1946-1954.

Rader, J. I., Wolnik, K. A., Gaston, C. M., Fricke, F. L. \& Fox, M. R. S. (1986). Purified reference diets for weanling rats: effects of biotin and cellulose. Journal of Nutrition 116, 1777-1788.

Reicks, M. \& Rader, J. I. (1990). Effects of dietary tin and copper on rat hepatocellular antioxidant protection. Proceedings of the Society for Experimental Biology and Medicine 195, 123-128.

Schosinsky, K. H., Lehmann, H. P. \& Beeler, M. F. (1974). Measurement of ceruloplasmin from its oxidase activity in serum by use of $o$-dianisidine dihydrochloride. Clinical Chemistry 20, 1556-1563.

Shankar, S., Sundaresan, P. R. \& Mohla, S. (1986). Effect of chronic administration of excess dietary vitamin A and zinc on lipid metabolism in rats. International Journal for Vitamin and Nutrition Research 56, 329-337.

Staab, D. B., Hodges, R. E., Metcalf, W. K. \& Smith, J. L. (1984). Relationship between vitamin A and iron in the liver. Journal of Nutrition 114, 840-844.

Sundaresan, P. R., Collins, T. F. X., White, K. E., Welsh, J. J., Black, T. N., Shackelford, M., Flynn, T., Newell, R. F. \& O'Donnell, M. W. (1994). Effect of ethanol and vitamin A excess on vitamin A status in liver, plasma, and foetuses of pregnant rats. Food and Chemical Toxicology 32, 247-254.

Sundaresan, P. R., Cope, F. O. \& Smith, J. C. Jr (1977). Influence of zinc deficiency on retinal reductase and oxidase activities in rat liver and testes. Journal of Nutrition 117, 2189-2197. 